Chained Branches와 Dark Fiber 병합 방식을 이용한 선박용 광 네트워크 감시 시스템 제작

\title{
Fabrication of Optical Network Monitoring Systems for Ship Using Combinations of Chained Branches Method and Dark Fiber Method
}

\author{
이성렬*, 곽재민 ${ }^{*}$, 류광수 ${ }^{* *}$, 황의창**, 황남석*** \\ Seong-Real Lee*, Jae-Min Kwak*, Kwang-Su Ryu ${ }^{* *}$, Eui-Chang Hwang ${ }^{* *}$, and Nam-Suk Hwang ${ }^{* * *}$ \\ 요 약
}

향후 대용량 정보 제공 서비스를 위한 선박용 광 네트워크 감시 시스템의 하드웨어와 소프트웨어를 설계 제 작하였고, 개발된 광 네트워크 감시 시스템이 선박이라는 특수 상황과 관련 있는 선로 연장, 매크로밴딩, 이물 질이 부착된 광 커넥터에 의한 손실 등 3가지의 이벤트를 정확히 모니터링하는지를 실험을 통해 확인해 보았 다. 감시 시스템의 하드웨어는 선박의 네트워크 구조에 맞는 chained branch와 dark fiber 병합 방식으로 설계 제작하였고, 3 가지 이벤트에 대한 감시 시험 결과 3 가지 모두 $5 \mathrm{~m}$ 이내의 범위로 모니터링하는 것을 확인하였 다.

\section{Abstract}

Hardware and software of optical network monitoring system for optical network installed in ship for providing massive information are designed and fabricated. And, we investigated whether the fabricated system will accurately monitoring three events of optical cable extension, macrobanding and ferrule dust, which are related with special situation of ship, or not through the experiment. We used the combined method of chained branch and dark fiber for designing and fabricating hardware of optical network monitoring system for optimal corresponding with network configuration in ship. And, we confirmed that the proposed system excellently trace within $5 \mathrm{~m}$ range of event point in all three cases by investigating each event experiments.

Key words : Optical network monitoring system, Chained branch, Dark fiber, OTDR, Optical event

\section{I. 서 론}

멀티미디어 기반 대용량 정보 서비스는 장소에 구
애받지 말아야 한다. 즉 항공기나 선박에서도 승무원 과 승객들을 대상으로 한 대용량 정보 제공과 네트워 크 서비스가 제공되어야 한다. 더욱이 e-Navigation을

\footnotetext{
* 목포해양대학교 해양정보통신공학과 (Department of Marine Inform. \& Comm. Eng., Mokpo National Maritime University)

** 신한포토닉스(주),

*** (주)금강산전

· 제1저자 (First Author) : 이성렬

· 교신저자 : 곽재민

· 투고일자 : 2012년 4월 4일

- 심사(수정)일자 : 2012년 4월 4일 (수정일자 : 2012년 4월 23일)

· 게재일자 : 2012년 4월 30일
} 
중심으로 한 조선-IT 융합에 따라 선박 내에서 생성되 고 처리되어야 하는 정보량은 더욱 증가될 것으로 예 상된다. 이는 선박용 네트워크의 기반이 동축 케이블 에서 광 케이블 중심으로 변화하는 계기를 제공한 것 이고, 이러한 추세를 반영하듯 현재 조선소에서 제조 되는 대형 크루즈 선박과 군함 등에는 통신 백본 선 로로 광 케이블을 적용하여 생산되고 있다[1]-[3].

크루즈 선박과 군함 등의 특수 선박에 설치된 광 네트워크를 운용하는데 있어 네트워크 구조의 최적 화, 데이터의 분산 처리 등의 통신 관련 기술 외에 광 네트워크에서 발생할 수 있는 이벤트의 항상적인 감시와 이벤트의 즉각적인 해결도 매우 중요하다. 광 네트워크에서 발생하는 이벤트는 광 케이블의 단 선 외에 커넥션 손실, 스플라이싱(splicing) 손실, 분 기 손실, 커넥터의 미접속에 의한 손실, 커넥터의 오 정렬 (mismatch와 misalignment)에 의한 손실 등 매우 다양하고, 더욱이 광 네트워크는 항상 염분에 노출 되어 있고 엔진의 저주파 진동에 영향을 받기 때문 에 이벤트에 대한 감시가 중요하다고 볼 수 있다. 아 울러 향후 e-Navigation과 같은 최첨단 시스템을 위한 통신망으로 광 네트워크가 사용된다면 선박의 안전 운항의 관점에서도 광 네트워크의 감시 기술 개발은 매우 필요하다.

따라서 본 연구에서는 대용량 정보 제공을 위한 선 박 내 광 네트워크가 안전하고 신뢰성 높은 서비스를 제공하기 위하여 필요로 하는 선박이라는 특수 공간 을 고려한 광 네트워크 감시 시스템 (monitoring system)을 설계 제작하였고, 육상이 아닌 선박 내에서 발생할 수 있는 이벤트(event)를 가정하고 각 이벤트 들을 모니터링한 시험 결과를 보고하고자 한다. 광선 로 감시 시스템의 기본은 OTDR (optical time domain reflectometer)이기 때문에 본 연구에서 사용한 감시 시 스템의 하드웨어의 핵심은 OTDR 모듈이며, 기존의 OTDR과 다른 점은 선박의 네트워크 구조에 맞게 chained branches 방식과 dark fiber 방식을 병합하여 다 채널 선로 감시가 가능하도록 개발하였다는 것이다.

II. 광 네트워크 감시 시스템의 원리 및 설계방식

\section{2-1. OTDR의 원리}

광 네트워크 선로 감시 시스템의 핵심 기술인 OTDR은 광섬유에 입사시킨 짧은 광 펄스는 광섬유 내부에 피할 수 없이 존재하는 불균일성들의 분포 때 문에 발생하는 레일리 산란(Rayleigh scattering)을 이 용한 것이다. 즉, 광섬유 내의 임의의 위치에서 입사 광의 일부가 거의 모든 방향으로 산란되는데, 이중 광 섬유의 수용각(acceptance angle) 내로 산란되는 빛들 은 되돌아오게 된다. 이러한 과정은 광섬유의 어느 특 정 부분에서만 생기는 것이 아니라 길이 전체를 따라 분포하여 일어나는 것으로서, 광섬유의 각 부분들이 후방 산란에 기여한다. 그러므로 광섬유의 끝에 광 검 출기를 적절히 배치하면, 모든 후방 산란된 광 펄스들 의 포락선인 신호를 얻을 수 있으며, 이 신호의 시간 적인 변화로부터 광섬유의 손실 특성을 알 수 있다 [4],[5].

\section{2-2 광 네트워크 감시 시스템 설계 방식}

광 네트워크 선로 감시 시스템의 설계 방식은 광섬 유 선별기 (fiber selector)를 이용하여 개개의 분기 광 심선(core)들을 차례로 감시하는 방법, 한 개의 감시 광 파장과 한 번의 측정으로 모든 분기 광 심선들의 상태를 파악하는 방법인 branch length training 방식, 감시 광 대역에서 감시 광을 여러 파장으로 나누고, 개별 분기 광 심선마다 하나의 감시 광을 할당하는 방법인 wavelength routing 방식, 감시 광이 모든 분기 광 심선을 순서대로 진행해 나가는 방법인 chained branches 방식, 서비스 중인 광 심선이 아닌 ONU(optical network unit)의 전 구간에 대하여 유휴 광 심선을 감시하는 dark fiber의 이용 방식이 있다 [5],[6].

본 연구에서 선내 광선로 네트워크 구성은 장비실 $(\mathrm{A} / \mathrm{B})$ 를 기준으로 트리 구조를 형성하고 하부 구조로 내려갈수록 링 구조 형태에 dark/live 광 심선을 갖게 하였으므로 광 선로 감시 시스템 방식 설정에 있어 chained branches 방식과 dark fiber 방식을 병합하여 다 채널 선로 감시가 가능하도록 개발 설계하였다. 즉 그 림 1과 같은 구조로 선내 광선로 구축 환경에 맞게 광 스위치와 $\mathrm{WDM}$ (wavelength division multiplexed) 필터 
를 사용하여 통신 운용 파장에 영향을 주지 않고 live 채널을 감시 할 수 있도록 개발 설계하였다.

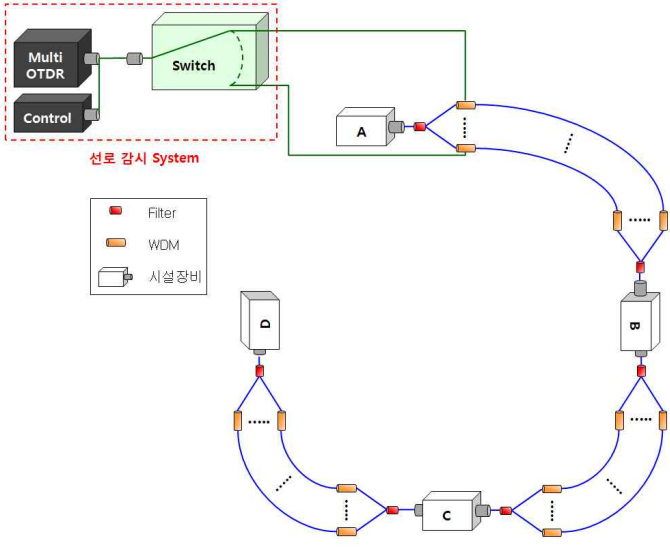

그림 1. 광 네트워크 감시 시스템의 구조

Fig. 1. Configuration of Optical network monitoring systems

III. 광 네트워크 감시 시스템의 설계 및 제작

\section{3-1.하드웨어 설계 및 제작}

광선로 감시 시스템의 하드웨어는 기본 구성과 기 능적 구성으로 크게 두 가지로 나누어 설계 제작하 였다. 기본 구성은 감시 시스템이 기본적으로 구동 하기 위해 필요한 하드웨어를 나타내고 있고, 기능 적 구성은 감시 시스템의 적용 어플리케이션에 따른 구성으로 구분하였다. 기본 구성은 메인 프레임, 프 로세서 모듈, 전원 공급 모듈, backplane 모듈, OTDR 모듈, 광 스위치 모듈, 시리얼/이더넷 모듈, 이더넷 제어 모듈, 쿨링 모듈로 구성되고, 기능적 구성은 OTDR 모듈과 광 스위치 모듈로 구성시켰다.

하드웨어의 주요 사양을 살펴보면, 마이크로프로 세서는 32 bit RISC processor (IBM Power PC embedded processor core), RAM은 DDR SDRAM, 인 터페이스는 Ethernet, USB, USART, IIC, SPI과 PCI로 구분하였고, 소비 전력은 $30 \mathrm{~W}$, 정격 퓨즈는 $2.5 \mathrm{~A}$, 스위칭 속도는 $25 \mathrm{~ms} /$ Port로 하였다. OTDR 모듈의 주요 사양은 표 1 과 같이 설계 제작하였다.

특수 선박 내 광 네트워크 선로를 모니터링하기 위한 시스템 설계는 실제 광 네트워크가 구축된 선 박 환경을 모형으로 설계되었으며 구축 환경에 따른
주요 고려 사항을 아래와 같이 설정하여 설계 제작 하였다.

0 선내 망 환경 : Tree 형태에 망 구성

0 실 사용 채널과 여분(spare) 채널에 비율 분석

0 설치된 다심 케이블에 따른 채널 사용량 분석

0 광 선로 주 네트워크 (main network) 시스템과부 네트워크 (sub network) 시스템 구간 연결 분석 0 이벤트 조건 분석

표 1. OTDR 모듈의 주요 사양

Fig. 3. Specifications of OTDR module.

\begin{tabular}{|c|c|c|}
\hline 구분 & Multimode & Single-mode \\
\hline 지 원 파장 & $850 \mathrm{~nm}, 1300 \mathrm{~nm}$ & $1310 \mathrm{~nm}, 1550 \mathrm{~nm}$ \\
\hline 다이나믹 레인지 & $24 \mathrm{~dB}$ & $40 \mathrm{~dB}$ \\
\hline Channel & 32 & 24 \\
\hline $\begin{array}{c}\text { 이벤트 및 감쇄 } \\
\text { 데드존 }\end{array}$ & \multicolumn{2}{|c|}{$0.5 / 2 \mathrm{~m}$} \\
\hline
\end{tabular}

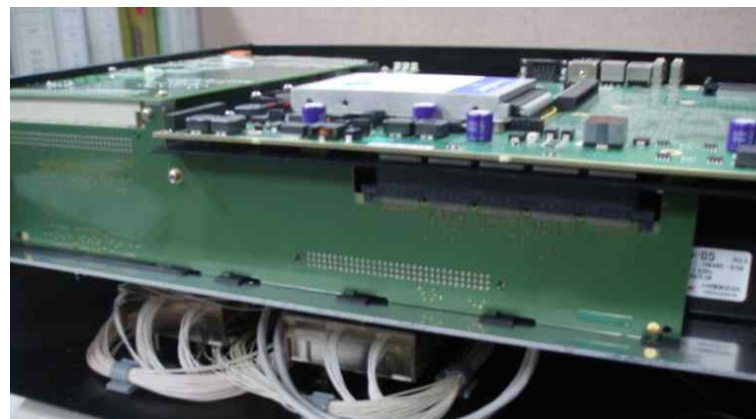

그림 2. 제작된 광 네트워크 감시 시스템

Fig. 2. Fabricated Optical network monitoring systems

OTDR 모듈은 광 스위치를 사용하여 단일 모드 광섬유 (SMF; single mode fiber)의 경우 최대 24 채 널, 다중 모드 광섬유 (MMF; multimode fiber)의 경우 최대 32 채널의 감시가 가능하도록 제작하였고, chained branches 방식을 사용하여 OTDR 지원 파장 을 $\mathrm{MMF}$ 인 경우 $850 / 1300 \mathrm{~nm}$ 와 $\mathrm{SMF}$ 인 경우 $1310 / 1550 \mathrm{~nm}$ 로 다수 파장에 따른 측정이 가능 하고 $\mathrm{WDM}$ 과 필터, isolater와 같은 수동소자를 선로 망에 시스템 전단에 구축하는 것으로 live 광선로와 dark 
광선로를 구분하여 측정 가능하도록 제작하였다.

또한 광 네트워크의 감시를 위한 주요 세부 내용은 다음과 같이 설정하였다.

0 광 시스템 간의 광선로의 상태 실시간 감시 기능

0 광선로 상의 전체 손실 (total loss) 측정

0 광선로 상의 optical return 손실 측정

0 광선로 상의 밴딩 유/무 확인

0 광선로 상의 수동 특성 상태 확인

0 광선로에서 사용되는 광섬유의 파장 특성 비교 측정

\section{3-2. 소프트웨어 설계 및 제작}

광선로 감시 시스템은 실질적인 광선로의 물리적 부분을 측정, 분석할 수 있도록 한 하드웨어 기반의 분석 개발 장비이기 때문에 소프트웨어는 하드웨어 에서 1 차적으로 분석된 결과를 기반으로 기준 측정 파형 대비 실시간으로 변화하는 파형을 상호 비교 감시하여 사용자에게 그 분석된 결과를 보여주며, 또한 분석된 결과를 $2 \mathrm{D}$ 또는 $3 \mathrm{D}$ 로 위치를 표시하여 광 선로 감시의 효율성을 증대 및 유지보수 시간을 단축시켜주는 것을 목표로 개발했다.

소프트웨어의 논리적 개발 환경은 Micosoft NET Framework 2.0 + XNA Framework 3.1(3D)을 기반으 로 개발되었다. 기본적인 프로그래밍 언어는 $\mathrm{C}++$ 을 채택하여 개발하였고, 통신 방식은 IP 기반의 이더넷 통신 방식과 포트를 사용하여 동시에 여러 개의 하 드웨어를 제어하는 방식을 채택 설계되었으며, Framework 3.1을 기반으로 그래픽 2D 및 $3 \mathrm{D}$ 까지 지 원이 가능하도록 개발하였다. $3 \mathrm{D}$ 디스플레이의 경우 Google Earth에서 제공하는 Sketch 소프트웨어를 기 반으로 X, Y, Z 좌표를 구현하여 선내 광선로 이상 유무를 육안으로 쉽게 확인할 수 있도록 설계 제작 되었다.

광선로 감시 시스템은 IP 기반으로 각각의 서로 다 른 포트를 할당하여 상호간에 제어를 하는 방식으로 사용자 제어 컴퓨터와 이더넷을 통해 제어되고, 명령 형식은 SCPI 기반의 command를 이더넷의 데이터에 실어 하드웨어를 제어하도록 하였다. 예를 들어, 메인 보드의 IP가 192. 168. 30. 101 Port 8002로 기본 설정 및 변경, 확인 및 수정을 수행할 수 있게 구현되었으
며, 192. 168. 30. 101 Port 8003은 내부의 OTDR을 제 어하여 측정을 수행하고, 192. 168. 30. 103 Port 4002 는 외부 광 스위치를 제어하는 형식이다.

광선로 감시 시스템의 소프트웨어는 감시 회선 정 보, 측정 관리, 장애 처리, 이력 관리, 통계 분석, 시 스템 관리 등의 기능이 나타나도록 설계 제작하였 다. 이러한 기능이 나타날 수 있도록 아래 세부 사항 들을 구현하였다.

0 시스템 설정 및 기능 제어 구현

- 감시 장비 설정 및 연결 확인 기능 구현

- 사용자 프로파일 설정

- 감시할 포트 설정

- 저장 파일 경로 및 파일 이름 설정

- 측정 시간 설정

0 실시간 감시 대상물에 대한 그래픽 툴 구현

- Tab Control Bar 사용 그래픽 화면 구분

- 채널 선택 기능 및 채널 추적(trace) 구분

- 소프트웨어 측정 지연 시간 설정

- 감시 대상물에 대한 display 환경 설정 및 위치 정보 설정 기능

- 이벤트 및 이상 유무 임계값 설정 (수동 이벤트 구역 설정 기능)

- 그래픽 및 display 화면 zoom(in/out) 기능 0 측정 결과 화면 툴 및 자동 분석 툴 구현

- 측정 결과 화면 툴 구현

- 측정 결과 자동 분석 (손실, 반사 및 거리, 위치 정보)

0 자동 알람 및 데이터 저장 기능 구현

- 알람 및 데이터 저장 on/off 기능

- 임계값 초과 시 자동 저장 기능 (시간 설정) 0 기타

- 오류 메시지 자동 저장

- display 화면 이벤트 클릭 시 내용 정보 확인 메시지 창

\section{$\mathrm{IV}$. 시험 측정 결과 및 분석}

\section{4-1. 시험 측정 준비 단계}

우선 제작된 선박용 광 네트워크 감시 시스템을 
통한 광 네트워크 이벤트 감시 시험을 위한 준비 단 계를 수행하였다. 이를 위해 $50.2 \mathrm{~m}$ 길이의 48심 더 미 케이불 (dummy cable), $27.3 \mathrm{~m}$ 의 2심 케이블, 3.1 $\mathrm{m}$ 의 2심 패치 코드 (patch cord)를 사용하여 기준 채 널을 설정하고 준비된 케이블과 패치 코드를 연결한 후 기준파를 측정하였다. 기준 채널 외의 타 채널에 동일한 조건을 설정하고 기준 채널과 비교하여 얻어 진 편차 값을 가지고 매개변수 및 시스템 내외 접속 상태를 수정하였다. 또한 감시 시스템의 소프트웨어 운용을 위한 측정 파라미터의 초기 값을 아래와 같 이 설정하였다.

$$
\begin{aligned}
& 0 \text { 측정거리 : } 0.0 \sim 2.0 \mathrm{~km} \\
& 0 \text { 펄스폭 : } 3 \mathrm{~ns} \\
& 0 \text { 측정 파장 : } 850 \mathrm{~nm} \\
& 0 \text { 굴절률 : } 1.465 \\
& 0 \text { sample distance : } 0.08 \mathrm{~m} \\
& 0 \text { Averaging : } 5 \mathrm{sec}
\end{aligned}
$$

\section{4-2. 이벤트 감시 측정}

본 연구에서 가정하고 시험한 이벤트는 선로 연 장, 매크로 밴딩과 페룰에 먼지 유입 (ferrule dust)의 3 가지 경우로, 이 중 매크로 밴딩은 선박이 격실 구 조로 되어 있다는 특성을 감안한 이벤트이며, ferrule dust는 선박이 항상 외부에 노출되어 있고 기관 등에 서 발생하는 분진의 영향을 고려한 이벤트로 선택한 것이다.

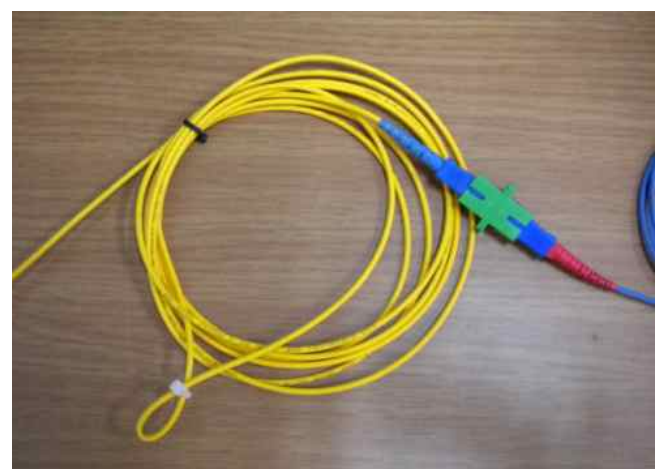

그림 4. 매크로 밴딩 이벤트를 위한 광 케이블

Fig. 4. Optical cable for macrobanding event

그림 4는 3 가지 이벤트 중 매크로 밴딩 시험을 위
해 사용된 말아 놓은 형태의 $27.3 \mathrm{~m}$ 의 케이블이고, 그림 5 는 ferrule dust 시험을 위해 사용된 이물질이 부착된 광 커넥터 내부 사진이다.

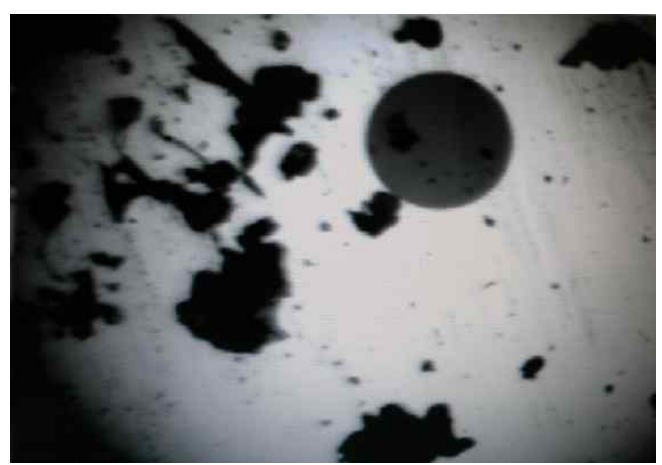

그림 5. 이물질이 부착된 광 커넥터 내부

Fig. 5. Inner part of optical connector with foreign substance such as dust

우선, 기준파 측정을 위한 파라미터들을 아래와 같이 설정하였다.

0 측정 거리 : $0.0 \sim 5.1 \mathrm{~km}$

0 펄스폭 : $3 \mathrm{~ns}$

0 측정 파장 : $1550 \mathrm{~nm}$

0 굴절률 : 1.465

o sample distance : $0.16 \mathrm{~m}$

0 Averaging : $20 \mathrm{sec}$

0 기준파용 더미 케이블 : 약 $50 \mathrm{~m}$ 의 단일 모드 케 이블

그림 6 은 기준파 측정에서 얻어진 광선로 감시 그 래프로 우선 $4.79 \mathrm{~m}$ 에서 dead zone이 관측되었다. 이 는 처음 입사 단의 광 커넥터에서 발생되는 반사광 에 기인하는 것이다. 그리고 $53.39 \mathrm{~m}$ 에서 반사파가 관측되는데 이는 더미 케이블의 종단점을 나타낸 것 이다. 여기서 실제 더미 케이블의 길이인 $50 \mathrm{~m}$ 와 다 르게 나타난 이유는 시스템 내부의 스위칭 모듈에 있는 여분의 광섬유 때문에 발생한 것으로 판단된 다. 또한 전반적으로 기준파 측정 파형 상태가 고르 지 못한 이유는 48심의 더미 케이블이 꼬여진 형태 로 구축되었기 때문에 나타난 결과이다.

그림 7은 선로 연장 이벤트를 감시한 결과를 나타 낸 그래프 (측정 파형을 기준파와 비교)와 데이터로, 본 측정에서 사용한 선로 연장 이벤트는 기준파 측 

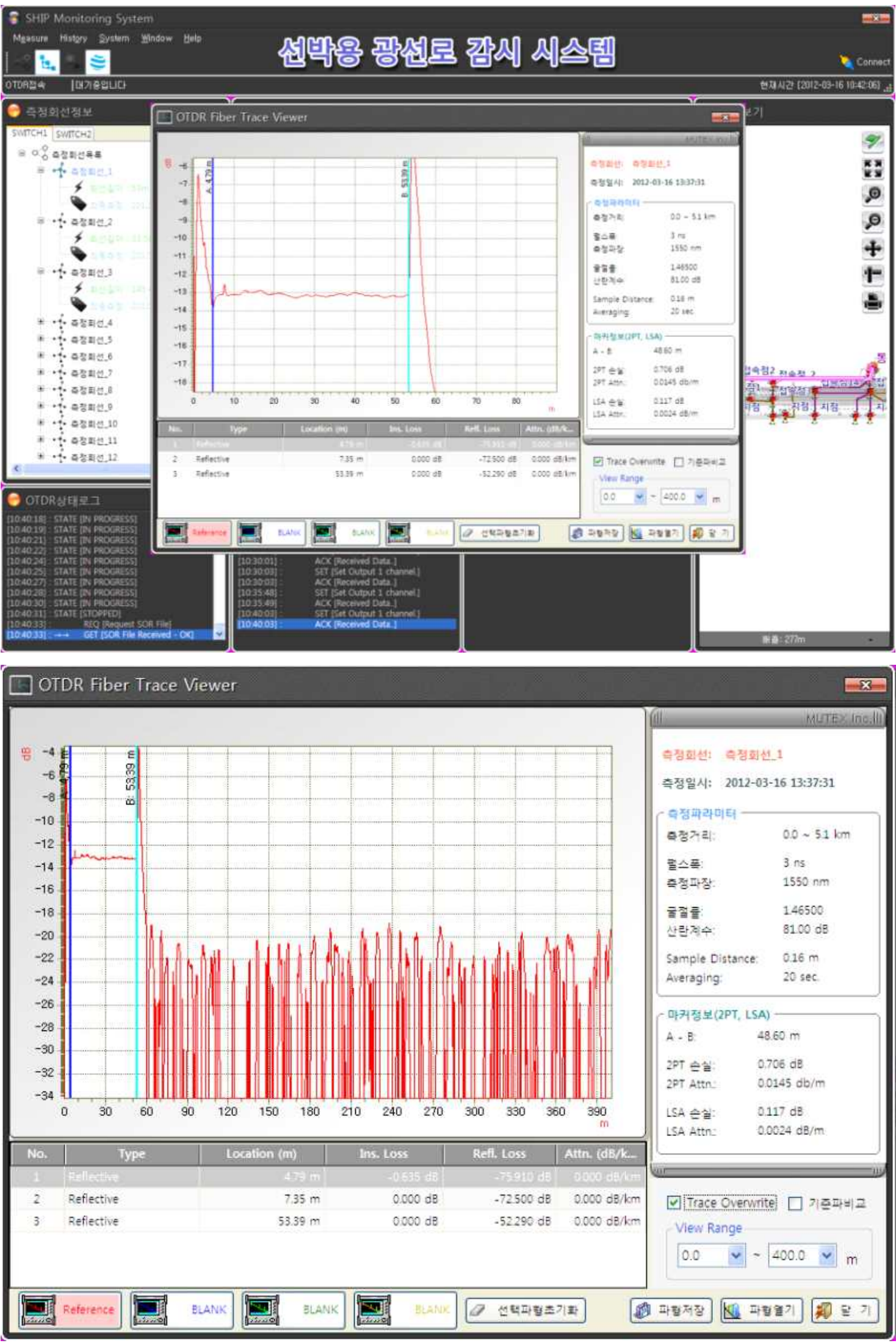

그림 6. 기준파 측정 결과

Fig. 6. Result of measuring reference wave. 


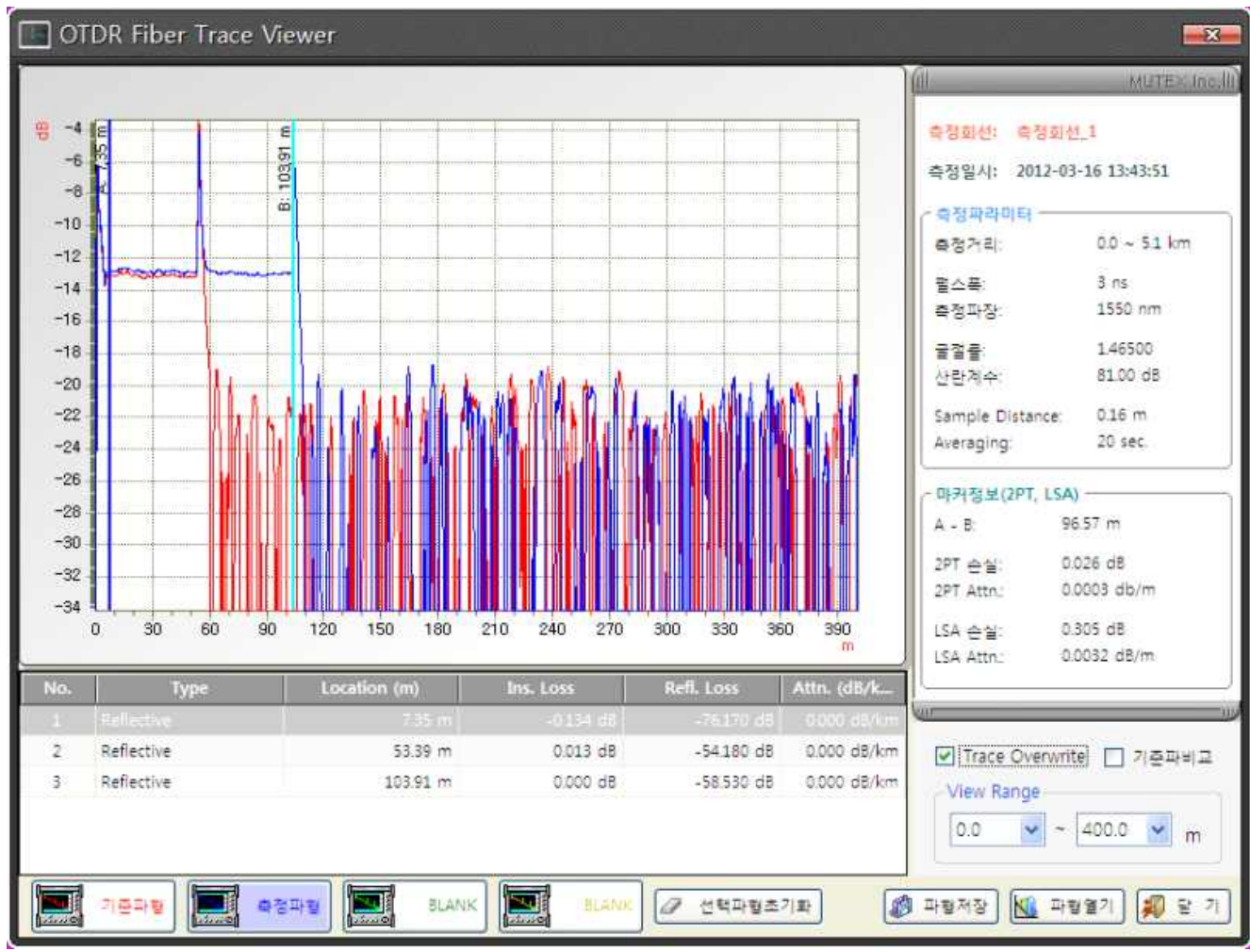

그림 7. 선로 연장 이벤트 측정 결과

Fig. 7. Monitoring result of optical cable extension event.

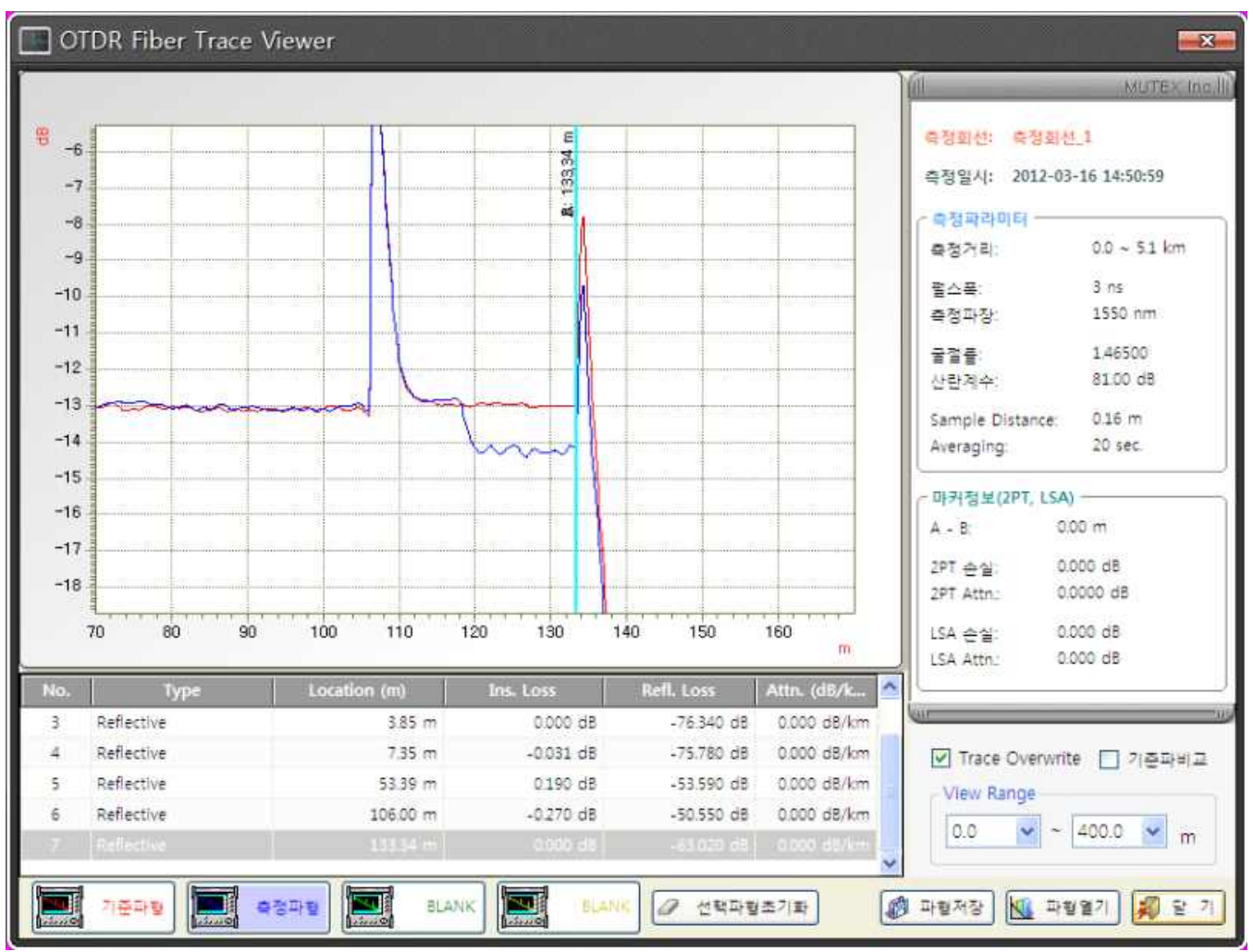

그림 8. 매크로밴딩 이벤트 측정 결과

Fig. 8. Monitoring result of macrobanding event.

정 시 사용된 $50 \mathrm{~m}$ 더미 케이블 2개를 연결한 형태 로 수행하였다. 그림 7에서 $53.39 \mathrm{~m}$ 에서 피크치가 나 


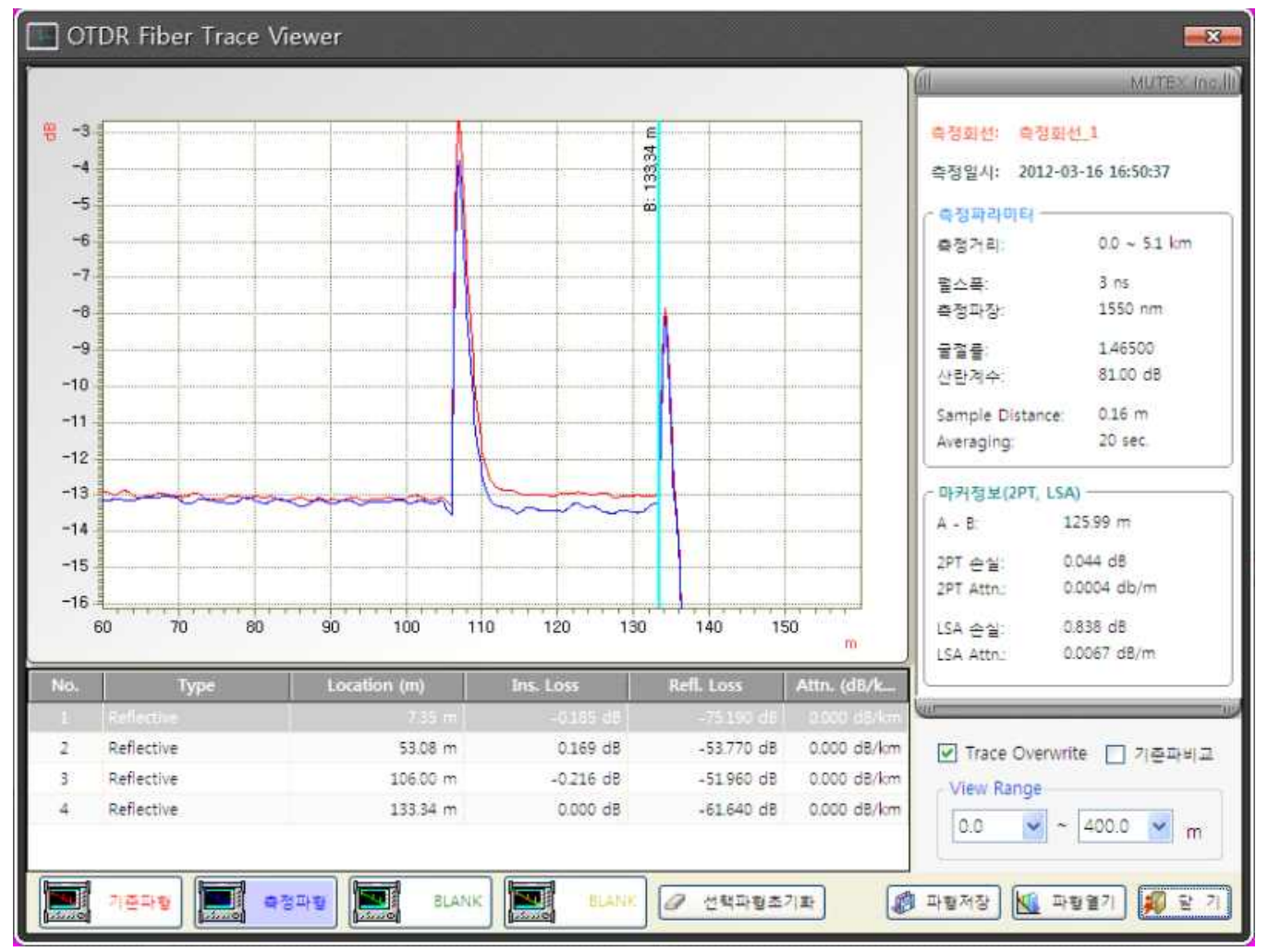

그림 9. ferrule dust 이벤트 측정 결과

Fig. 9. Monitoring result of ferrule dust.

타나는데 이는 선로 연장에 따른 커넥터의 접속 손 실을 보여주는 것이다. 또한 $103.91 \mathrm{~m}$ 에서 나타난 피 크치는 선로 종단을 나타낸 보여주고 있는 것이다.

그림 8 은 매크로 밴딩 이벤트를 감시한 결과를 나 타낸 그래프로, 본 측정에서 사용한 매크로 밴딩 이 벤트는 선로 연장 이벤트에 사용된 케이블에 약 27.3 $\mathrm{m}$ 의 케이블을 추가 연결하고 추가된 케이블 중간 지 점에 그림 4 와 같이 케이블을 감아서 매크로 밴딩이 나타나도록 하였다. 그림 8을 살펴보면, 약 $108 \mathrm{~m}$ 지 점부터 광 전력이 감소하는 것을 확인할 수 있다. 즉 이 $108 \mathrm{~m}$ 부터 매크로 밴딩이 나타난 것을 확인할 수 있다. 또한 $133.34 \mathrm{~m}$ 에서 나타난 피크치는 이 이벤트 의 경우 선로 종단이 133.34 인 것을 알려주는 결과이 다.

그림 9는 ferrule dust 이벤트를 감시한 결과를 나 타낸 그래프로, 본 측정에서 사용한 ferrule dust 이벤 트는 선로 연장 이벤트에 사용된 $100 \mathrm{~m}$ 의 케이블 다 음에 이물질이 묻은 커넥터를 통해 약 $27.3 \mathrm{~m}$ 의 케 이블을 추가 연결하여 설정하였다. 그림 9 를 살펴보 면, $106 \mathrm{~m}$ 이후 지점에서 ferrule 단면에 이물질로 인
한 IL 손실이 나타나고 운용자 측정 파형에서 구간 손실이 발생하는 것으로 ferrule dust의 이벤트를 확 인할 수 있다.

\section{V. 결 론}

지금까지 선박에 설치된 광 네트워크를 감시하기 위한 시스템의 Chained Branches 방식과 Dark Fiber 방식을 병합한 하드웨어와 소프트웨어의 설계와 제 작에 대해 살펴보았고 선로 연장, 매크로 밴딩과 ferrule dust의 3 가지 이벤트를 감시하는 시험을 통해 개발된 감시 시스템의 기능과 성능을 확인해 보았 다.

본 연구에서 제작한 선박용 광 네트워크 감시 시 스템은 고려한 3가지 이벤트 모두를 양호하게 모니 터링함을 알 수 있었다. 또한 본 논문에서 언급하지 않았지만 커넥터 접속 손실 이벤트, 커넥터 오접속 이벤트, 단선 이벤트와 스플라이싱 이벤트도 모두 양호하게 모니터링하는 것을 확인하였다. 이들을 논 
문에서 언급하지 않은 이유는 이들 이벤트 모두 선 박 외의 육상 등의 일반적인 상황에서 나타나는 이 벤트이고 다른 광선로 감시 장치에서도 양호하게 모 니터링되기 때문이다.

본 시험에서 확인한 감시 오차, 즉 resolution은 약 $5 \mathrm{~m}$ 내외로 세계적 수준이기는 하지만 좀 더 정확한 감시와 고품질 네트워크 서비스를 위해서는 감시 오 차를 $1 \mathrm{~m}$ 이내로 줄여야 한다. 따라서 향후 연구에 서는 본 연구를 통해 확인된 사항들을 바탕으로 감 시 오차를 줄이는 것을 목표로 할 계획이다.

감사의 글

본 연구는 지식경제부 호남광역경제권 선도산업 육성사업의 연구비 지원에 의해 수행되었습니다.

\section{참 고 문 헌}

[1] 정보통신연구진흥원 정보조사분석팀, "IT 융합 산 업의 발전 동향 분석", IT Insight, 2008. 6.

[2] 임동선, 김재명, 박운용, "조선-IT 융합기술 : e-Navigation 동향", TTA Journal, No.119, 2008. 9-10.

[3] 박정호, 진광자, 김재명, 유대승, 오문균, 임동선, “조선 IT 현황과 전망”, 전자통신동향분석 제 25 권 제4호, 2010. 8.

[4] 최영복, 권병성, 박수진, "FTTH(PON) 감시 기술 동향," 주간기술동향, 제1393호 pp. 1-12, 2009. [5] 이우람, 조승현 김봉규, 박재동, 김병휘, "파장분할 다중방식 광통신망의 모니터링 방식에 관한 기술 동향," 전자통신동향분석 제19권 제5호, 2004.

[6] R. Hui, and M. O'Sullivan, Fiber Optic measurement Techniques, Academic Press, 2009.

[7] 한재용, 이경득, 이순흠, “효율적인 다기능 감시 단말기 설계 및 구현," 한국정보기술학회논문지 제권 제6호 2009. 12.
이 성 렬 (李成烈)

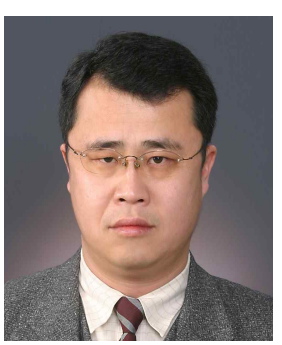

1990년 2월 : 한국항공대학교 통신 정보공학과 (공학사) 2002년 2월 : 한국항공대학교 대학원 통신정보공학과 (공학박사) 1996년 1월 2002년 5월 : (주)세영통신 전파기술연구소 책임연구원 2002년 6월 2004년 2월 : (주)에이티엔 기술연구소장

2004년 3월 현재 국립목포해양대학교 해양정보통신 공학과 부교수 관심분야 : WDM 시스템, 광의 비선형 현상 분석

곽 재 민 (郭宰旼)

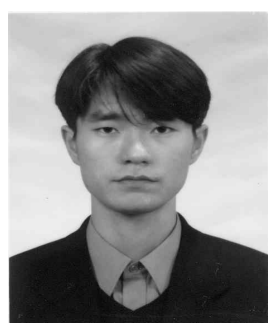

1998년 2월 : 한국항공대학교 통신 정보공학과(공학사)

2002년 8월 : 한국항공대학교 대학원 통신정보공학과(공학박사) 2002년 7월 2003년 7월 : 한국전자 통신연구원 네트워크 연구소 (Post-doc.) 2003년 7월 2008년 2월 : 전자부품 연구원 $\mathrm{SoC}$ 연구센터책임연구원

2008년 3월 현재 : 목포해양대학교 해양정보통신공학과 조교수

관심분야 : 디지털 통신 시스템, 유무선 통신신호처리

\section{류 광 수 (柳光洙)}

1997년 3월 2005년 2월: 동신대 정보통신공학과 졸업 2010년 8월 현재 : 전남대 산업대학원 전자공학과 재학 2009년 5월 현재 : 신한포토닉스(주) 선임 연구원 관심분야: $\mathrm{FBG}$, 광 센서 시스템, 광 계측기

\section{황 의 창 (黃義昶)}

1991년 3월 1997년 2월 : 아주대 재료공학과 졸업 1996년 12월 1998년 8월: KCC그룹 근무 2001년 8월 현재 : 신한포토닉스(주) 연구소장

황 남 석

1999년 2003년 : 대불대학교 경영정보학과 졸업 2012년 현재 : 목포대학원 전기공학과 석사과정 2005년 현재 : 금강산전(주) 대표이사 